\title{
Diffuse cerebral petechial hemorrhage in an 8-year-old girl with MRSA pneumonia and sepsis
}

Figure Susceptibility-weighted MRI of cerebral hemispheres

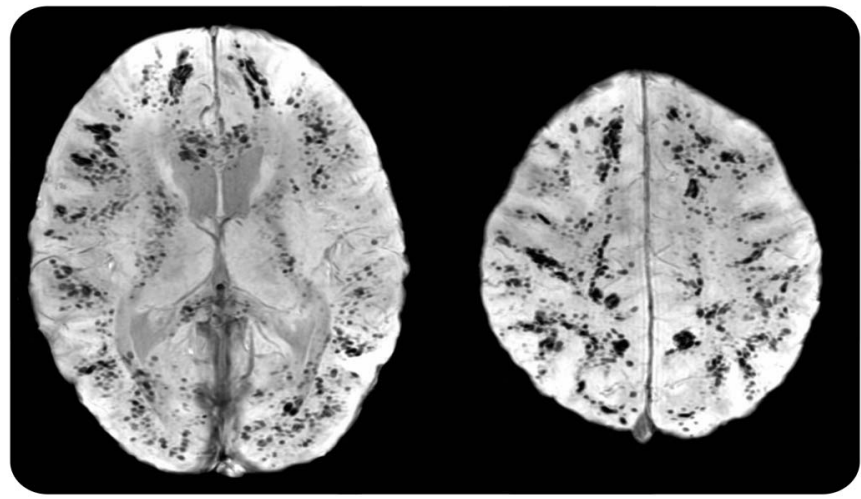

Innumerable discrete petechial hemorrhages throughout the cerebral hemispheres demonstrated on axial susceptibilityweighted MRI. The majority of the lesions are located at the gray-white interface.

An 8-year-old girl in septic shock due to necrotizing methicillin-resistant Staphylococcus aureus (MRSA) pneumonia developed signs of end-organ damage, new right hemiplegia, and left gaze preference. Susceptibilityweighted MRI demonstrated extensive multifocal petechial hemorrhage preferentially at the gray-white matter interface due to septic microemboli (figure). Mechanisms of hemorrhage include small-vessel occlusion leading to mycotic aneurysm formation with rupture or pyogenic arteritis without aneurysm formation. ${ }^{1}$ Intracranial hemorrhage associated with metastatic staphylococcal infections is rarely described ${ }^{2}$ and is especially noteworthy with diffuse cerebral petechial hemorrhage in the setting of metastatic MRSA.

Mitchel T. Williams, MD, Huiyan Jiang, MD

From the Department of Neurology, Children's Hospital of Michigan, Wayne State University, Detroit.

Author contributions: M. Williams: study concept and design, acquisition and interpretation of data, writing of draft manuscript.

$\mathrm{H}$. Jiang: discussion of case and revision of manuscript.

Study funding: No targeted funding reported.

Disclosure: The authors report no disclosures relevant to the manuscript. Go to Neurology.org for full disclosures.

Correspondence to Dr. Williams: mitchelwilliams8@gmail.com

1. Masuda J, Yutani C, Waki R, Ogata J, Kuriyama Y, Yamaguchi T. Histopathological analysis of the mechanisms of intracranial hemorrhage complicating infective endocarditis. Stroke 1992;23:843-850.

2. Pniitt AA, Rubin RH, Karchmer AW, Duncan GW. Neurologic complications of bacterial endocarditis. Medicine 1978;57: 329-343. 


\title{
Neurology
}

\author{
Diffuse cerebral petechial hemorrhage in an 8-year-old girl with MRSA pneumonia and \\ sepsis \\ Mitchel T. Williams and Huiyan Jiang \\ Neurology 2014;82;282 \\ DOI 10.1212/WNL.0000000000000039
}

This information is current as of January 20, 2014

\section{Updated Information \&} Services

References

Subspecialty Collections

Permissions \& Licensing

\section{Reprints}

including high resolution figures, can be found at: http://n.neurology.org/content/82/3/282.full

This article cites 2 articles, 1 of which you can access for free at: http://n.neurology.org/content/82/3/282.full\#ref-list-1

This article, along with others on similar topics, appears in the following collection(s):

All Imaging

http://n.neurology.org/cgi/collection/all_imaging

Bacterial infections

http://n.neurology.org/cgi/collection/bacterial_infections

Intracerebral hemorrhage

http://n.neurology.org/cgi/collection/intracerebral_hemorrhage

Pediatric stroke; see Cerebrovascular Disease/ Childhood stroke http://n.neurology.org/cgi/collection/pediatric_stroke_see_cerebrovasc ular_disease-childhood_stroke

Information about reproducing this article in parts (figures,tables) or in its entirety can be found online at:

http://www.neurology.org/about/about_the_journal\#permissions

Information about ordering reprints can be found online:

http://n.neurology.org/subscribers/advertise

Neurology ${ }^{\circledR}$ is the official journal of the American Academy of Neurology. Published continuously since 1951, it is now a weekly with 48 issues per year. Copyright @ 2014 American Academy of Neurology. All rights reserved. Print ISSN: 0028-3878. Online ISSN: 1526-632X.

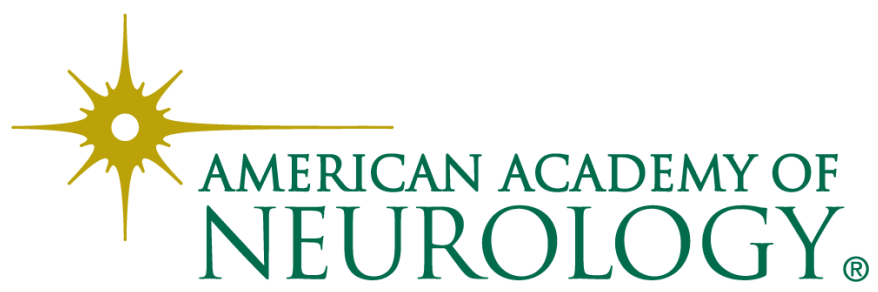

